\title{
Integrated Farming System- A Livelihood Security Tool for Rural Small and Marginal Farm Families
}

\author{
J.S. Hilli*, Sarojani Karakannavar, C.J. Kumar and Harshavardhan J. Hilli \\ Department of Seed Science and Technology, College of Agriculture, University of \\ Agricultural Sciences, Dharwad-580005, Karnataka (India) \\ *Corresponding author
}

\begin{tabular}{|c|}
\hline Keywords \\
\hline $\begin{array}{l}\text { Integrated farming } \\
\text { system, Security }\end{array}$ \\
\hline Article Info \\
\hline $\begin{array}{l}\text { Accepted: } \\
20 \text { November } 2018 \\
\text { Available Online: } \\
10 \text { December } 2018\end{array}$ \\
\hline
\end{tabular}

\section{A B S T R A C T}

\section{Introduction}

During last few decades agriculture research has focused on development of high yielding crop varieties/hybrids, good farm machineries, crop production and plant protection technologies which enabled the farmers to harvest higher yield but at the same time it was exploited the resources much and decreased the productivity and profitability. After experiencing the fact, farmers are looking towards the interacted farming system (IFS) which has been advocated as a tool for harmonious use of inputs and reduce the burden on farmers by combining different components like field crops. Vermicompost, dairy, poultry, vegetable cultivation and floriculture for production of profitable and sustainable agriculture with continuous cropping system without maintaining the soil health causing the lower yield as well as depleting the nutrients. Integrated Farming System (IFS) interact appropriately with the environment without dislocating the ecological and social economic balance for enhancing the lively wood of farmers. The 
potential integration of dairy, poultry, vegetable cultivation, floriculture with suitable cropping system should be exploited to make judicious use of farm inputs and natural resources so as to provide, regular income and employment to small land holders for maximum number of days. These farmers generally practice subsistence farming where they need to produce a continuous reliable and balanced supply of food as well as cash for basic needs and recurrent farm expenditure. There for, there is need to develop suitable integrated farming system for such farmers. Single crop production enterprises are subjected to high degree of risk and uncertainty because of seasonal, irregular and uncertain income and employment to the farmers. IFS is proper integration of different components which may pave the way for realizing increased productivity and profitability to small and marginal farmers and which would be the potential way to decrease production costs by synergetic recycling of bio-products of various components within the system and also to provide a regular source of income and employment. Thus IFS is a reliable way to obtain higher productivity with sustainable nutrient economy in combining with max compatibility and replacement of organic matters and integration between each enterprise.

\section{Materials and Methods}

The IFS modules were implemented in selected villages of transnational belt of Dharwad district. Under the project entitled "Empowerment of SC/ST families through IFS approach" for three years viz. 2012-13, 2013-14 and 2014-15. The number of farmers / farm women was selected based on the base line data of farmers on socio-economic condition of farmers, technologies and farming system practiced by the farmers. Under this study 40 farmers were selected on the total area of 24 ha. The rainfall was ranging from $750-900 \mathrm{~mm}$, the soil of the study area was red loamy with low nutrient content. During the study, the farmers were practicing field crops alone viz., cotton, paddy, and maize-chick pea cropping system during the season and after cropping season farmers were used to move urban areas in search of job to fulfill their basic needs and few of them remain in the villages for grazing the animals. Looking into the situation, it was felt that introduction of components like dairy, vermicompost unit, vegetable cultivation, poultry and floriculture which provides additional income as well as employment to farmers round the year. Hence the farmers were given technology on cultivation of vegetables, flowers along with critical inputs viz., seeds of tomato, chilli, brinjal, marigold and crysanthamum. Further the animal component was also introduced which helped in recycling the animal waste in to FYM and also production of vermicompost using farm wastes. The farmers were also given 10 chicks of Giriraja breed for meat purposes. Along with these allied enterprises farmers cultivated the field crops which have been depicted in Table 1.

The farmers of the selected villages were given frequent training on the techniques on lowering the cost of cultivation, seed treatment with rhizobium, trichoderma to reduce the disease incidence and increase the yield. Farmers were taken for the exposure visit to the demonstration plots of University of Agriculture Sciences, Dharwad viz., Agri/Silvi/horti systems, sheep and goat rearing units, vermicomposting, vermi wash, floriculture unit and dairy. The farmers were more interested in taking up vegetable, dairy and vermicompost activities. They were trained on clean milk production and nutritional aspects of milk, its products and the importance for vulnerable group's viz. Children, pregnant, lactating and old age. Further the visit was made to IGFRI, through 
which they learnt on various fodder crops and grasses. All these changed their outlook to agriculture. The farmers were also provided with cow/buffalo through the project for improving the livelihood of farmers. The improved fodder seeds/grass slips were made available to the SC/ST farmers of Dharwad district. The farmers were encouraged and all the farmers came forward to implement the IFS module on their farm.

\section{Results and Discussion}

The results of the programme implemented are shown in the tables. The results obtained from the 40 farmers of Amblikoppa, Halligeri and Muraktti villages of Dharwad district is discussed below with the PRA and the results revealed that all farmers belonged to small farmers category with land holding of less than 2 to 5 acres. Among them, majority of farmers 62.5 per cent practicing rainfed farming, 27.5 percent had bore well irrigation facility and only 10 per cent had farm found. The soil type of these farmers was red loamy. The cropping system before implementation of integrated farming system was maize during Kharif followed by chick pea in Rabi season. During the off time the farmers used to move to the urban area for carrying out works in building construction, carpentry, retail grocery shops and house hold works etc. To enhance the livelihood security of SC/ST small and marginal farmers, a core group of scientists from KVK interviewed with farmers for various activities to suit to their farming system followed by the trainings, consultancy, exposure visits and providing critical inputs. Comparison of economic status after implementation of IFS module is presented in Table 2.

The grass income obtained from different components under IFS was Rs.1,57,640/(2011-12), Rs.1,75,000/- (2012-13) and $1,81,200 /-$ (2013-14) and average of three year was Rs. 1,71,280/- as against Rs. 50,000/- (2011-12), Rs.56,200/- (2012-13), Rs. 58,000/- (2013-14) averaging to Rs.54,733/- from sequential cropping system of maize during kharif followed by Bengal gram (rabi) or conventional farming system. By practicing IFS with the different components viz., vermicompost, dairy, composting, poultry and vegetable cultivation the net returns of the farm was increased to the tune of 58.38 per cent.

The employment generation in the farming system was almost round the year and it was increased to the tune of more than $50 \%$ when compared to before practice of integrated farming system (174 days/ years). The increase in gross return, net return and No. of man days was due to the practices of different farming system in a year and that lead to additional income to the farmers. The similar results were reported by Yogesh et al., (2016), Jahan et al., (2011), Ugwumba et al., (2010) and Sachinkumar et al., (2012)

Table.1 Area occupied by individual component

\begin{tabular}{|r|l|l|}
\hline Sl. No. & \multicolumn{1}{|c|}{ Particular } & \multicolumn{1}{|c|}{ Area } \\
\hline $\mathbf{1}$ & Vermicompost & \\
\hline $\mathbf{2}$ & Dairy (2 Cows) & 4 gunta \\
\hline $\mathbf{3}$ & FYM & \\
\hline $\mathbf{4}$ & Vegetables & 5 gunta \\
\hline $\mathbf{5}$ & Floriculture & 1 gunta \\
\hline $\mathbf{6}$ & Cropping system & 30 gunta \\
\hline
\end{tabular}


Table.2 Comparison of economic status before and after implementation of integrated farming system

\begin{tabular}{|l|l|l|l|l|l|l|l|l|l|l|l|}
\hline $\begin{array}{l}\text { S1. } \\
\text { No. }\end{array}$ & Particulars & $\begin{array}{l}\text { Prior } \\
\text { to IFS }\end{array}$ & \multicolumn{2}{|c|}{$2012-13$} & \multicolumn{2}{|c|}{$2013-14$} & \multicolumn{2}{|c|}{$2014-15$} & \multicolumn{2}{|c|}{ Average } & $\%$ \\
\hline $\mathbf{1}$ & $\begin{array}{l}\text { Gross } \\
\text { return (Rs) }\end{array}$ & 90,000 & 157640 & 50000 & 175000 & 56200 & 181200 & 58000 & 171280 & 54733 & 52.55 \\
\hline $\mathbf{2}$ & $\begin{array}{l}\text { Cost of } \\
\text { Cultivation } \\
\text { (Rs) }\end{array}$ & 35,000 & 73950 & 18000 & 77700 & 20000 & 79250 & 21000 & 76966 & 19667 & 45.47 \\
\hline $\mathbf{3}$ & $\begin{array}{l}\text { Net return } \\
\text { (Rs) }\end{array}$ & 55,000 & 83390 & 32000 & 97300 & 36000 & 101950 & 37000 & 94213 & 35000 & 58.38 \\
\hline $\mathbf{4}$ & $\begin{array}{l}\text { B:C ratio } \\
\mathbf{5}\end{array}$ & 2.6 & 2.1 & 2.7 & 2.3 & 2.8 & 2.3 & 2.8 & 2.2 & 2.8 & \\
\hline $\begin{array}{l}\text { No. of Man } \\
\text { Days }\end{array}$ & 150 & 365 & 170 & 365 & 175 & 365 & 178 & 365 & 174 & 41.10 \\
\hline
\end{tabular}

*IFS: Integrated Farming System, ${ }^{* *}$ CS: Cropping system

Table. 3 Gross return and cost of cultivation of different components

\begin{tabular}{|l|l|c|c|c|c|c|c|}
\hline $\begin{array}{l}\text { Sl. } \\
\text { No. }\end{array}$ & \multicolumn{1}{|c|}{ Particulars } & \multicolumn{2}{|c|}{$2012-13$} & \multicolumn{2}{c|}{$2013-14$} & \multicolumn{2}{c|}{$2014-15$} \\
\hline $\mathbf{1}$ & Vermicompost & 7500 & 2000 & 8000 & 2000 & 8000 & 2000 \\
\hline $\mathbf{2}$ & $\begin{array}{l}\text { Dairy (Milk Yield- } \\
\text { 2cows) }\end{array}$ & 79200 & 54450 & 84200 & 55000 & 86200 & 55200 \\
\hline $\mathbf{3}$ & FYM (Cow dung) & 5840 & - & 6400 & - & 6500 & - \\
\hline $\mathbf{4}$ & $\begin{array}{l}\text { Poultry } \\
\text { Chicks) }\end{array}$ & 12500 & 1000 & 13500 & 1200 & 14000 & 1300 \\
\hline $\mathbf{5}$ & $\begin{array}{l}\text { Vegetable } \\
\text { cultivation }\end{array}$ & 17600 & 5000 & 19600 & 5800 & 20000 & 6000 \\
\hline $\mathbf{6}$ & Floriculture & 7000 & 1500 & 8300 & 1700 & 8500 & 1750 \\
\hline $\mathbf{7}$ & Cropping System & 28000 & 10000 & 35000 & 12000 & 38000 & 13000 \\
\hline
\end{tabular}

${ }^{*}$ GR: Gross return, **COC: Cost of Cultivation

\section{Different components of IFS module}

The different components including the IFS module were presented in the Table 3. During lean period, activities viz compost preparation, vermicompost production poultry birds rearing activities were taken up along with vegetable and flower cultivation. Farm family consisted farmer, his wife and two children and were used to work on the farm. The IFS module which was implemented on one acre land was compared with their traditional cropping system which was also practiced on one acre.

In conclusion IFS enhances productivity, profitability and nutritional security of the farmer and sustains soil productivity through recycling of organic resources.

In this system, animals were grazed on agriculture waste, production of vermicompost, the most notable advantage of utilizing low-cost/ no-cost material at the farm level for recycling is that it will certainly 
reduce the production cost and ultimately improve the income considerably.

\section{References}

Yogesh, L. N., Prashant, S. M., Sheik, P. P. and Kamble, A. S., 2016. Promotion of integrated farming system for enhancing the livelihood of Farmers in Ballari district of Karnataka. Int. J. Sci. Environ. 5(5): 3630-3634.

Jhana, K. M. and Pemsl, D. E., 2011, The Impact of Integrated AquacultureAgriculture on small scale Farm Sustainability and farmers livelihoods: Experience from Bangaladesh. Agric
Systems. 104:392-402.

Sachinkumar, T. N., Basavaraj, H., Kunnal, L. B., Kulkarni, G. N., Mahajanashetty, S. B., Hunsyal, C. S. and Hosamani, S. V. 2012, Economics of farming System in Northern Transitional Zone of Karnataka. Karnataka J. Agril. Sci. 25(3): 350-358.

Ugwumba, C. O. A., Okoh, R. N., Nnabuife, E. L. C. and Orji, E. C. 2010. Integrated farming system and its effect on farm cash income in Awka South Agricultural Zone of Anambra State, Nigeria. American-Eurasian J. Agril. Environ. Sci. 8(1): 1-6.

\section{How to cite this article:}

Hilli, J.S., Sarojani Karakannavar, C.J. Kumar and Harshavardhan J. Hilli 2018. Integrated Farming System- A Livelihood Security Tool for Rural Small and Marginal Farm Families. Int.J.Curr.Microbiol.App.Sci. 7(12): 2817-2821. doi: https://doi.org/10.20546/ijcmas.2018.712.320 